\title{
Self-determination Theory as Mediator in the Nexus of Gamification and Customer Purchasing Behaviour
}

\author{
Lubica Gajanova ${ }^{1, *}$, Mladen Radišić ${ }^{2}$ \\ ${ }^{1}$ Department of Economics, The Faculty of Operation and Economics of Transport and Communications, University of Žilina, \\ Univerzitna 1, 010 26, Zilina, Slovakia \\ ${ }^{2}$ Department of Industrial Engineering and Engineering Management, Faculty of Technical Sciences, University of Novi Sad, Trg \\ Dositeja Obradovića 6, 21000 Novi Sad, Serbia
}

\begin{abstract}
Gamification in marketing can be understood as the use of game mechanisms to motivate customers and encourage them to behave in a specific way and interact in some activities or communities in order to increase their satisfaction, loyalty and commitment, thereby contributing to brand building. There are many foreign works confirming the benefits of gamification. However, there is an absence of any known studies explicitly conducted into gamification within a marketing context in the Slovak Republic. This paper therefore attempts to address this kind of research gap and answer the question of whether gamification is a more effective form of promotion for improving the purchasing behaviour of customers in Slovakia. The results of the research confirm that gamification as part of sales promotion has a positive effect on the purchasing behaviour, search intentions and attitudes of Slovak customers. The results also indicate the positive mediation role of motivation based theory related to gamification and customer purchasing behaviour.
\end{abstract}

Keywords: gamification; motivation; self-determination theory; purchasing behaviour

\section{Introduction}

The term gamification has been known in research since 2002, but increased attention has been paid to it since 2010 [1]. Between 2011 and 2013, the concept of gamification quickly came to the forefront of information technology trends due to its emplacement in the Gartner Hype Cycle. However, Gartner's 2014 Hype Cycle refuted this assumption and shifted gamification down the curve to the Trough of Disillusionment - to hybrid clouds and augmented reality [2]. The reasons why gamification can be considered a future trend are: the growth of the gaming industry [3], the expansion of the use of smartphones and wearable technologies [4], and the increasing application of the concept of quantified self [5]. Gamification complements all these areas perfectly.

The positive effect of gamification in marketing has been confirmed by many scientists and practitioners [6-12]. This can be explained by the fact that companies are able to achieve a competitive advantage using innovation and knowledge about users in a progressive form of marketing communication [13-17]. However, there is an absence of any known studies explicitly conducted into gamification within a marketing context in the Slovak Republic. The research is also justified when taking into account the singularity and parochialism of Slovak peoples' perception of brand, as described by Kliestikova and Janoskova [18]. They say that Slovak customers are, from the psychological point of view, still conservative, with strong tendencies towards their historical socio-political heritage, this despite accelerating globalization and related processes and phenomena, which they are not aware of. This postulate has been proven in practice when foreign and domestic brands have applied either their original branding patterns or patterns copied from effective foreign practice for brand building and which have led to the opposite effect - an undesirable decline in brand value. This paper therefore attempts to address this kind of research gap and answer the question of whether sales promotions with gamification elements are a more effective form of promotion in terms of improving the purchasing behaviour, search intentions and attitudes of Slovak customers.

\section{Literature Review}

To date, there is no generally accepted definition of gamification [19]. According to Shauchenka [20] the most common definition comes from Deterding, Dixon and Khaled [6]: gamification is the use of game design elements in non-game contexts. The Oxford Dictionary defines gamification as the application of typical elements of game playing (e.g. point scoring; competition with others; rules of play) to other areas of activity, typically as an online marketing

\footnotetext{
*Corresponding author: lubica.gajanova@fpedas.uniza.sk
} 
technique that encourages engagement with a product or service. In their publication on the implementation of game elements in web and mobile applications, Zichermann and Cunningham [21] define gamification as the process of gamethinking and game mechanics to engage users and solve problems. It follows from their definition that the main goal of gamification is to achieve interaction with the customer, and on this basis to achieve the desired goal [22, 23]. According to Graessley et al. and Princes, gamification can be applied to any problem that can be solved by influencing human motivation and behaviour [24, 25]. Chaffey [26] defines gamification as the process of applying game principles and mechanics to ordinary activity in order to actively engage customers through rewards, engagement or amusement. The goal of the successful application of gamification elements should be to increase customer loyalty. Burke [19] argues that gamification focuses on motivating players to meet their goals with the intention of meeting the specific goals of the organization that implements gamification. Gamification in marketing is integrated into an external form of gamification, which aims to target customers through playful ways in the external environment of the company. However, the goal is not to force customers to participate in these games. Rather, companies are trying to adjust well-established processes to make them more fun and playful for their customers. Gaming mechanisms are then a way for customers to become addicted to the company and be more loyal to its products or brand [27]. In general, gamification is considered to be a system that can force customers to enjoy participating in business services, resulting in increased customer loyalty or increased customer retention [28].

According Koch et al. [29], 25\% of gamification comes down to technology, the remaining $75 \%$, psychology. The success of gamification is obviously due to psychological reasons [30,31]. The aim of gamification is to motivate users to do things that they would not have been able to do without the use of game elements. It's about influencing existing behaviour and creating a positive experience for the player to motivate them to repeat the activity. Motivation is the key element with which gamification works. To better understand it, it is necessary to explain the basic psychological theory dealing with the phenomenon of motivation in the context of gamification.

Self-Determination Theory (SDT) is based on the traditional theory of intrinsic and extrinsic motivation. The structure of internal motivation describes a person's natural propensity for adaptation, acquisition, spontaneous interest and exploration, which is so important to cognitive and social development and which is a vital source of pleasure and vitality in life. In other words, if we are motivated internally, we do the activity not because of the separable effect or outcome but for our own satisfaction or interest and for the pleasure of the activity itself $[32,33,34]$. External motivation then refers to an activity that is performed for the purpose of a certain result that is separable from the activity, for example reward. When comparing people who are motivated internally to those who are more controlled from the outside, the first group show greater interest, excitement and confidence, which in turn translates into increased performance, stamina and creativity [35]. Internal motivation also has a longer-term effect [36]. If we combine this theory with gamification, it can be said that while its aim is to increase internal motivation, gamification itself is actually an application of external motivators [37]. Gamification combines the above-mentioned types of motivation. On the other hand, it motivates from the outside by means of play elements and subsequent rewards. It tries to evoke feelings or needs that motivate us internally. According to self-determination theory, the dominant form of motivation for playful behaviour can be assigned to intrinsic motivation [38]. Since gamification makes use of playful elements, this could lead to intrinsically motivated behaviour. In the context of gamified sales promotions, this means that gamification, through the playful elements, can stimulate an intrinsic confrontation of the customer's involvement in game elements, and therefore in the promotional offer. From a company's point of view, the intrinsic motives caused by gamification could therefore have a positive effect on variables such as customer relationship, promotion perception, customer satisfaction, loyalty and purchasing behaviour.

\section{Methodology}

The research question is whether sales promotions with gamification elements are a more effective form of promotion for improving the purchasing behaviour, search intentions and attitudes of Slovak customers. The survey was conducted in March 2020 by means of the CAWI method. A total of 399 respondents participated in the study.

A basic set of surveyed respondents was formed of Slovak citizens older than 15 years. That age limit was set as one of the essential prerequisites for autonomous decision-shopping, in accordance with valid Slovak law [39]. The size of the representative sample was determined by the following equation:

$$
\mathrm{n} \geq\left[\mathrm{t} \alpha^{\wedge} 2 \times \mathrm{p} \times(1-\mathrm{p})\right] / \mathrm{d}^{\wedge} 2
$$

Where: $\mathrm{n}$ - the minimum number of respondents; $\mathrm{t} \alpha$ - the critical value of the normal distribution at significance level $\alpha=0.05 ; \mathrm{p}$ - the likely sample proportion, expressed as a decimal; $\mathrm{d}$ - the confidence interval, expressed as a decimal [40]. The confidence level was set at $95 \%$. The critical value of the normal distribution at confidence level $\alpha=0.05$ was 1.96. This is based on the fact, that $\%$ of the area of the normal distribution is within 1.96 standard deviations of the mean. For those cases where the likely sample proportion was not known, $\mathrm{p}$ was set at $50 \%$. The confidence interval was set at $5 \%$. With these parameters, the minimum sample size is 384 . So the number of respondents in the survey can be considered as sufficient [41]. To answer the research question, the hypothesis was set as follows. There is a statistical dependence between the preferred type of promotion and its impact on purchasing behaviour, search intentions and the attitudes of customers. 
The hypothesis is based on the basic competence of gamification, namely that the use of game mechanisms and game elements can direct human behaviour in a desired direction [6, 42]. Gamification motivates people to show a desired behaviour [12]. For example, Murray and Bellman [43] report a positive effect of gamification on purchasing behaviour, and Lounis, Neratzouli, and Pramatari [12] have shown that gamification can increase the willingness to pay for sustainable products. Siemens et al. [44] also concluded that gamification has a positive effect on consumer attitudes. Based on this, gamification is expected to have a motivating strengthening effect, which leads to improved promotional efficiency by guiding purchasing behaviour in a desired direction. In particular, gamification is expected to increase shopping intentions, reduce search intentions and have a positive impact on consumer attitudes (consisting of satisfaction and loyalty to the retailer and satisfaction with the shopping experience). Given that gamification is mostly a psychological aspect, the hypothesis was analysed not only in terms of total direct effect between the variables examined but also with the use of mediators to specify the relationship between independent and dependent variables through the inclusion of explanatory variables (motivation based theory).

Respondents' answers to the following questions were used as input variables: (1) Which form of promotion do you prefer?; and (2) to what extent does the preferred form of promotion influence your shopping behaviour? In order to properly understand the questions and thus ensure relevant answers, explanatory notes were also included in the questionnaire. In the first question, concerning the determination of the preference of the form of promotion, the respondents had the possibility to choose between classical sales promotions and gamified sales promotions. Classical sale promotion was described as a non-monetary sale promotion because it is comparable to gamified sales promotion in terms of intrinsic motivation. In addition, a study by Kevin \& Clancy shows that only $15-35 \%$ of consumers are price sensitive [45]. Respondents could express the degree of influence of the preferred form of promotion on their shopping behaviour using a 5-point Likert scale. Respondents were asked to rate the effects of the promotion with regards to increasing their purchasing intentions, reducing their search intentions and the positive impact on their attitudes (consisting of satisfaction and loyalty to the retailer and satisfaction with the shopping experience).

When confirming the existence of a statistical dependence between the two examined variables, it is necessary to deal with the internal structure of the relationships. To achieve this, the data was more comprehensively analysed using an index, an expression that measures each value based on its relative significance to the other values in the contingency table. The index indicates the relative significance of a particular value in a pivot table cell (nij) relative to other cells and the total number of responses (n). The index calculates the weight that an item contributes to the overall total. The index compares each value to its row total, its column total, and the overall total, using a weighted average [46].

Given that gamification is mostly a psychological aspect, the hypothesis was analysed not only in terms of total direct effect between the examined variables, but also with the use of mediators to specify the relationship between independent and dependent variables through the inclusion of explanatory variables (motivation based theory) [47]. Mediators are an interesting research method to investigate the expected indirect effect of gamification on purchasing behaviour, and therefore on promotional effectiveness. For this, Intrinsic Motivation Inventory (IMI) was used. This is a multidimensional measurement device intended to assess participants' subjective experience related to a target activity. The instrument assesses participants' interest/enjoyment, perceived competence, effort, felt pressure and tension, perceived choice and usefulness while performing a given activity, therefore yielding six subscale scores [48]. Each aspect was described and respondents were asked to answer using a 7 point Likert scale, where 1 was "not at all true" and 7 was "very true". Aspects were described as follows:

- I enjoyed doing this activity very much because it was fun to do, it was interesting and quite enjoyable (Interest/Enjoyment).

- I think I am pretty good at this activity compared to other ones as well, so I felt competent, satisfied with my performance and pretty skilled at this activity (Perceived Competence).

- I put a lot of effort into this, I tried very hard on this activity because it was important to me to do well at this task (Effort/Importance).

- I did not feel nervous, anxious and tense at all while doing this, on the contrary I was very relaxed (Pressure/Tension).

- I believe I had some choice about doing this activity and I did it because I wanted to (Perceived Choice).

- I believe this activity could be useful, important, beneficial and of some value to me (Value/Usefulness).

Figure 1 illustrates the investigation of multiple mediation within the context of this paper. 
A
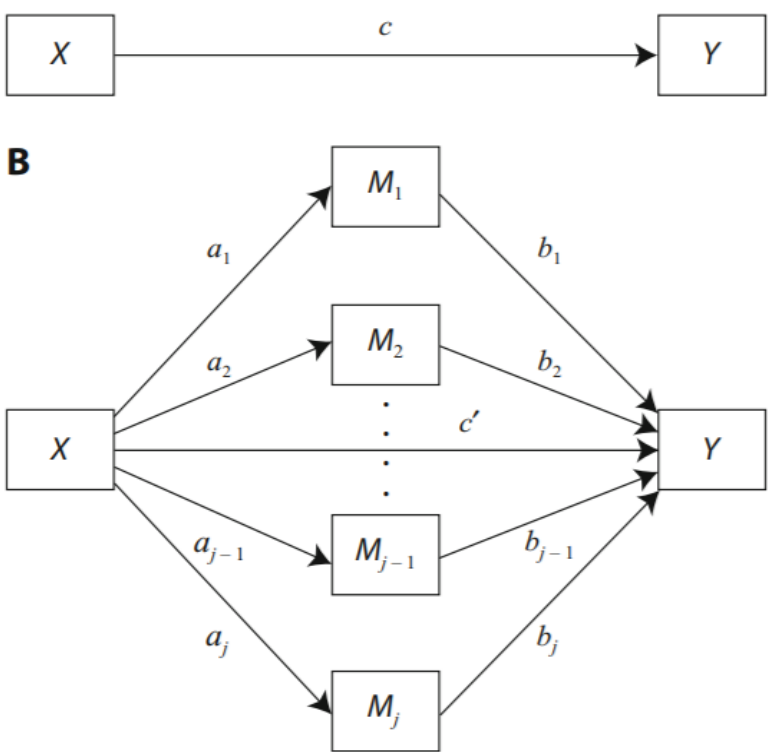

Figure 1. Illustration of multiple mediation with j mediators. (A) X affects $\mathrm{Y}$. (B) $\mathrm{X}$ is hypothesized to exert indirect effects on $\mathrm{Y}$ through $\mathrm{M} 1, \mathrm{M} 2, \ldots \mathrm{Mj}$.

Source: Preacher and Hayes [49].

IBM SPSS statistical software was used to test the mediation effect by PROCESS - a tool developed for conditional process modelling in SPSS. In all the analyses presented below, the significance of the indirect effect was obtained by computing $95 \%$ confidence intervals using 5,000 bootstrap samples.

\section{Results}

When testing the mediating path, it is possible to find out the direct and indirect effect of the independent variable to the dependent variable. The values for the direct effect of the preferred type of promotion on purchasing behaviour (in terms of shopping, search intentions and the attitudes of customers) are shown in Table 1.

Table 1. Direct effect of promotion type on purchasing behaviour

\begin{tabular}{|c|c|c|c|c|c|c|}
\hline \multicolumn{7}{|l|}{ Direct effect of X on Y } \\
\hline Effect & se & $\mathrm{t}$ & $\mathrm{P}$ & LLCI & ULCI & $\mathrm{c}^{\prime}$ ps \\
\hline 0.3984 & 0.0899 & 4.4314 & 0.0000 & 0.2217 & 0.5752 & 0.3063 \\
\hline
\end{tabular}

Source: Authors' calculation - SPSS.

Based on the results $(\mathrm{p} \leq 0.05)$ it is clear that there is a statistically significant relationship between the dependent and the independent variable. After confirming the dependence, we examined the internal relationships between the variables using the Index. The calculations are shown in Table 2.

Table 2. Indexes of responses

\begin{tabular}{|l|c|c|c|c|c|}
\hline Type of promotion & $\begin{array}{c}\text { Strongly } \\
\text { agree }\end{array}$ & Agree & Neutral & Disagree & $\begin{array}{c}\text { Strongly } \\
\text { Disagree }\end{array}$ \\
\hline Gamified sales promotion & 1.279828 & 1.366815 & 0.668924 & 0.716432 & 0.467031 \\
\hline Classical sales promotion & 0.607229 & 0.485133 & 1.464703 & 1.398021 & 1.748083 \\
\hline
\end{tabular}

Source: Authors based on Dalgleish [39].

Put simply, the index expresses the degree of protrusion or backwardness in a given sample. That is, how much the index for a particular cell loses to or exceeds 1 . We can therefore say that gamified sales promotions have a clear positive effect on purchasing behaviour, while the preference for classical sales promotions has a negative one. It is therefore established that there is a statistically significant impact of the type of promotion on purchasing behaviour that may be mediated. The results of the structural model analysis in Table 3 and 4 suggest that the type of promotion has a statistically significant impact on purchasing behaviour, search intentions and the attitudes of customers, even when a six path mediator is included. 
Table 3. Indirect effect of promotion type on mediators

\begin{tabular}{|c|c|c|c|c|c|c|}
\hline \multirow[b]{2}{*}{ Mediators } & \multicolumn{6}{|c|}{ Impact of $X$ on mediators } \\
\hline & coeff & se & $\mathrm{t}$ & $\mathrm{P}$ & LLCI & ULCI \\
\hline Interest/Enjoyment & 0.3596 & 0.1554 & 3.5927 & 0.0004 & 0.2528 & 0.8639 \\
\hline Perceived Competence & 0.3660 & 0.1639 & 3.6590 & 0.0003 & 0.2775 & 0.9221 \\
\hline Effort/Importance & 0.2947 & 0.1634 & 2.9292 & 0.0036 & 0.1574 & 0.7998 \\
\hline Pressure/Tension & 0.3349 & 0.1600 & 3.3393 & 0.0009 & 0.2197 & 0.8487 \\
\hline Perceived Choice & 0.3697 & 0.1609 & 3.6974 & 0.0002 & 0.2786 & 0.9114 \\
\hline Value/Usefulness & 0.3381 & 0.1657 & 3.3718 & 0.0008 & 0.2330 & 0.8847 \\
\hline
\end{tabular}

Source: Authors' calculation - SPSS.

Table 4. Indirect effect of mediators on purchasing behaviour

\begin{tabular}{|c|c|c|c|c|c|c|}
\hline \multirow[b]{2}{*}{ Mediators } & \multicolumn{6}{|c|}{ Impact of mediators on $\mathrm{Y}$ and mediating impact of $\mathrm{X}$ on $\mathrm{Y}$} \\
\hline & coeff & se & $\mathrm{t}$ & $\mathrm{P}$ & LLCI & ULCI \\
\hline Interest/Enjoyment & 0.3184 & 0.0388 & 9.2641 & 0.0000 & 0.2101 & 0.3233 \\
\hline Perceived Competence & 0.1969 & 0.0275 & 5.6851 & 0.0000 & 0.1022 & 0.2103 \\
\hline Effort/Importance & 0.2607 & 0.0275 & 7.5938 & 0.0000 & 0.1548 & 0.2629 \\
\hline Pressure/Tension & 0.0938 & 0.0274 & 2.7889 & 0.0055 & 0.0226 & 0.1304 \\
\hline Perceived Choice & 0.1205 & 0.0288 & 3.3827 & 0.0008 & 0.0408 & 0.1540 \\
\hline Value/Usefulness & 0.2288 & 0.0273 & 6.5852 & 0.0000 & 0.1263 & 0.2338 \\
\hline Type of promotion & 0.3063 & 0.0899 & 4.4314 & 0.0000 & 0.2217 & 0.5752 \\
\hline
\end{tabular}

Source: Authors' calculation-SPSS.

All estimated paths for the indirect effect were statistically significant $(\mathrm{p} \leq 0.05)$, so the mediators of intrinsic motivation Interest/Enjoyment, Perceived Competence, Effort/Importance, Pressure/Tension, Perceived Choice, Value/Usefulness completely mediates the path between the type of promotion and purchasing behaviour (Figure 2).

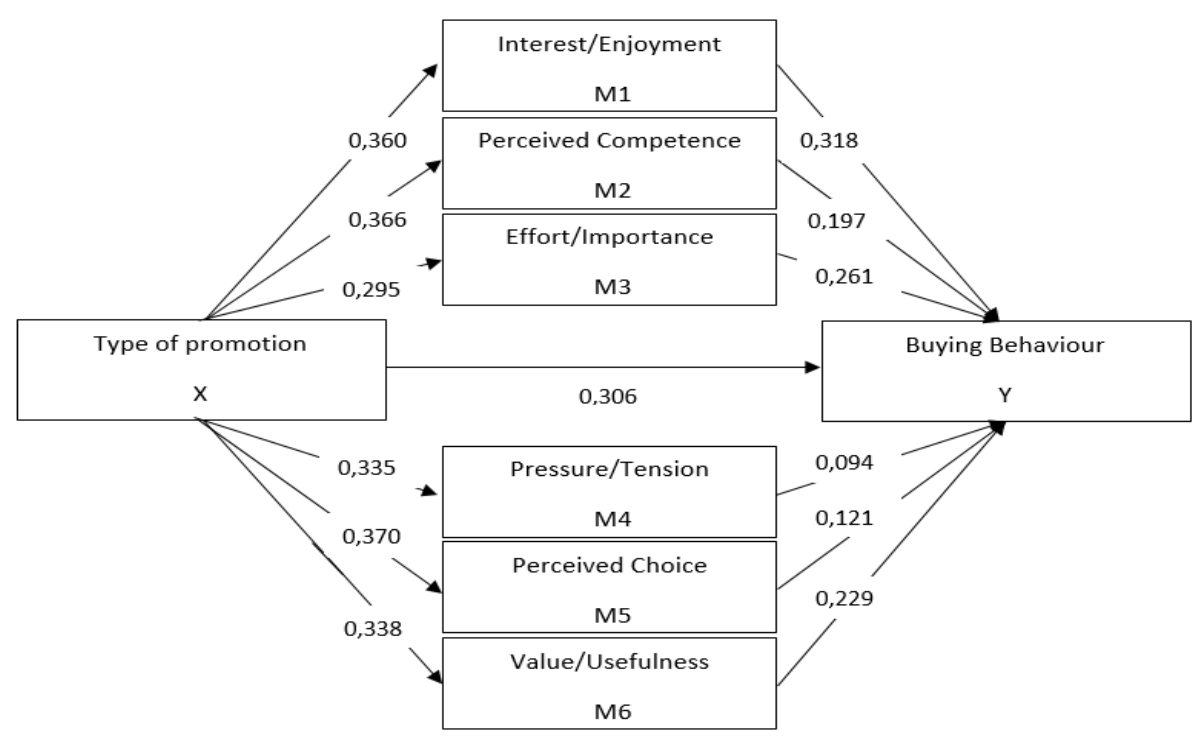

Figure 2. Multiple mediation model

Source: Authors.

\section{Discussion}

Based on the confirmed effect of the promotion type on the mediators analysed, it is possible to conclude that gamified sales promotions generate intrinsic motivation among consumers. Intrinsic motivation caused by gamified sales promotion is desirable for companies, because internally motivated customers buy not only because of price promotion, which is a manifestation of extrinsic motivation. The choice of a product by internally motivated customers is based on 
positive feelings such as satisfaction or affinity. Intrinsic motivation is also linked to greater stability [35], and therefore it can be assumed that truly motivated customers will continue to buy from the same retailer, company or brand. In support of this, Rigby [50] states that the meeting key psychological needs [51] in relation to games maintains the engagement of participants. In addition, intrinsic motivation leads to greater enjoyment [38], which could be expressed in a business context by satisfaction with the purchase and / or seller; because, according to Rheinberg, Vollmeyer and Engeser [52], intrinsic motivation has a positive effect on consumer behaviour. Based on these findings and in line with the results of the survey, we can say that the internal motivation caused by gamified sales promotion has a positive effect on consumers' shopping behaviour, and therefore leads to improved promotional effectiveness. Intrinsic motivation therefore acts as a mediator between gamification and purchasing behaviour. Previous research has shown that intrinsic motivation usually motivates people to play games [38]. Therefore, we assume that the application of game mechanisms and elements of gamification evoke internal motives. With a suitable game design that is based on self-determination theory and, above all, satisfies key internal psychological needs, gamified sales promotions are expected to evoke intrinsic motivation.

\section{Conclusion}

Consumer trends and the tough competitive situation in retail make it clear that retailers need to be creative in order to successfully initiate purchasing impulses through promotions. This situation indicates the need for innovative promotional concepts such as gamification. This is based on the assumption that, according to foreign secondary data, gamification has the potential to bring an additional advantage, and therefore achieve a strengthening effect, which in turn increases the effectiveness of promotions. This paper focused on confirming this assumption for Slovak customers, too. Within this context, this paper attempts to answer the question of whether sales promotions with gamification elements are a more effective form of promotion for improving the purchasing behaviour, search intentions and the attitudes of Slovak customers. The results clearly show that gamified sales promotion has a statistically significant positive impact on purchasing behaviour, both in general terms and in accordance with the specific relationships between variables according the use of mediators of intrinsic motivational character.

The limitation of the research may be the fact that it is not possible to draw clear conclusions from the perspective of consumers. The actual point of view may differ from reality. Sometimes it happens that a respondent deliberately conceals or does not admit facts for various reasons, even if the questionnaire is anonymous, which results in an idealized and partially distorted response [53]. To remove limitations of this kind, it is advisable to repeat the questionnaire survey on another sample of respondents. The questionnaire survey was conducted only in the presence of a geographically limited population. From a certain point of view, this may represent another limitation to this paper. This can be removed if the research results are subsequently verified and compared within an international environment. If these barriers were removed, more accurate results could be achieved.

\section{Acknowledgement}

This contribution is a partial output of the project APVV-15-0505: Integrated Model of Management Support for Building and Managing Brand Value in the Specific Conditions of the Slovak Republic.

\section{References}

1. F. Groh, Gamification: State of the Art - Definition and Utilization. In M. Asaj, et al., Proceedings of the 4th Seminar on Research Trends in Media Informatics. 39-46 (2012)

2. J. Simoes, Using Gamification to Improve Participation in a Social Learning Environment. In I. Buchemet al., Proceedings of The PLE Conference 2013: Learning and Diversity in the Cities of the Future. 167-184 (2013)

3. I. Koksal, Video Gaming Industry \& Its Revenue Shift [online]. Available at: https://www.forbes.com/sites/ilkerkoksal/2019/11/08/video-gaming-industry--its-revenueshift/\#46336bdd663e (2019)

4. A. Holst, Wearable technology - Statistics \& Facts [online]. Available at: https://www.statista.com/topics/1556/wearable-technology/ (2020)

5. R. Rawassizadeh, E. Momeni, C. Dobbins, P., Mirza-Babaei, R. Rahnamoun, Lesson Learned from Collecting Quantified Self Information via Mobile and Wearable Device. Journal of Sensor and Actuator Networks. 4(4), 315-335 (2015)

6. S. Deterding, D. Dixon, R. N. Khaled, L. Nacke, From Game Design Elements To Gamefulness: Defining "Gamification". In A. Lugmayr et al., Proceedings of the 15th International Academic MindTrek Conference: Envisioning Future Media Environment. 9-15 (2011)

7. E. Plessis, Jak zákazník vnímá značku: Nahlédněte s pomocí neurovědy do hlav spotřebitelů [How the customer perceives the brand: With the help of neuroscience, look into the heads of consumers]. Brno: Computer Press (2011) 
8. I. Kuo, Gigya's Social Gamification Boosts Content Discovery by $68 \%$ [online]. Available at: https://www.gamification.co/2013/03/28/gigya-boosts-content-discovery/ (2013)

9. D. Zadákov, Trendy na sociálních sítích v roce 2019. Co by vám nemělo uniknout? [Trends on social networks in 2019. What should you not miss?] [online]. Available at: https://www.evisions.cz/blog-2018-11-12-trendyna-socialnich-sitich-v-roce-2019-co-by-vam-nemelo-uniknout/ (2018)

10. Z. Zéman, A. Bogdan, Marketing strategy and building brand value on the Hungarian market. Ekonomickomanazerske spectrum. 13(2), 1-9 (2019)

11. J. Hamari, Transforming Homo Economicus into Homo Ludens: A Field Experiment on Gamification in a Utilitarian Peer-To-Peer Trading Service. Electronic Commerce Research and Applications. 12(4), 236-245 (2013)

12. S. Lounis, X. Neratzouli, K. Pramatari, Can Gamification Increase Consumer Engagement? A Qualitative Approach on a Green Case. In: C. Douligeris et al., Proceedings of Conference on e-Business, e-Services and eSociety. 200-212 (2013)

13. W. Sroka, J. Cygler, B. Gajdzik, The Transfer of Knowledge in Intra-Organizational Networks: A Case Study Analysis. Organizacija, 47(1), 24-34 (2014)

14. A. Domańska, Cooperation between knowledge-based institutions and business: empirical studies and network theories. Forum Scientiae Oeconomia. 6(4), 81-94 (2018)

15. L. Lizbetinova, P. Starchon, S. Lorincova, D. Weberova, P. Prusa, Application of Cluster Analysis in Marketing Communications in Small and Medium-Sized Enterprises: An Empirical Study in the Slovak Republic. Sustainability. 11(8), 2302 (2019)

16. L. Lizbetinova, P. Starchon, D. Weberova, E., Nedeliakova, M. Jurikova, The Approach of SMEs to Using the Customer Databases and CRM: Empirical Study in the Slovak Republic. Sustainability. 12(1), 227 (2020)

17. H. Palus, H. Matova, A. Krizanova, J. Parobek, A survey of awareness of forest certification schemes labels on wood and paper products. Acta facultatis xylologiae Zvolen. 56(1), 129-138 (2014)

18. J. Kliestikova, K. Janoskova, Branding with understanding: how national profile of consumer influences brand value perception. Marketing and management of innovations. (3), 149-157 (2017)

19. B. Burke, Gamify: How gamification motivates people to do extraordinary things. Brookline, MA: Biblomotion. (2014)

20. N. Shauchenka, Gamification. In: A. Ternes, I. Towers, Internationale Trends in der Markenkommunikation. Wiesbaden: Springer Fachmedien, 33-50 (2014)

21. G. Zichermann, C. Cunningham, Gamification by design: Implementing game mechanics in web and mobile apps. Sebastopol: O’Reilly Media (2011)

22. E. Alani, S. Kamarudin, L. Alrubaiee, R. Tavakoli, A model of the relationship between strategic orientation and product innovation under the mediating effect of customer knowledge management. Journal of International Studies. 12(3), 232-242 (2019)

23. J. Kliestikova, A. Krizanova, T. Corejova, P. Kral, E. Spuchlakova, Subsidies to Increase Remote Pollution? Science and Engineering Ethics. 24(2), 755-767 (2018)

24. S. Graessley, J. Horak, M. Kovacova, K. Valaskova, M. Poliak, Consumer Attitudes and Behaviors in the Technology-Driven Sharing Economy: Motivations for Participating in Collaborative Consumption. Journal of Self-Governance and Management Economics. 7(1), 25-30 (2019)

25. E. Princes, Boosting impulse buying behaviour in marketing management: customer satisfaction perspective. Polish Journal of Management Studies. 20(2), 403-413 (2019)

26. D. Chaffey, F. Ellis-Chadwick, Digital Marketing. Strategy, implementation and practice. Pearson Education Limited (2016)

27. A. Krizanova, J. Majerova, T. Kliestik, P. Majercak, Theoretical Aspects of Brand Building in Seafood Industry. Naše More. 60(5-6), 105-112 (2013)

28. A. Asquer, Not Just Videogames: Gamification and its Potential Application to Public Services [online]. Digital Public Administration and E-Government in Developing Nations: Policy and Practice. 146-165 Available at: https://papers.ssrn.com/sol3/papers.cfm?abstract_id=2429345 (2014)

29. M. Koch, F. Ott, S. Oertelt, Gamification von Business Software - Steigerung von Motivation und Partizipation [Gamification of business software - increasing motivation and participation]. Neubiberg: Universität der Bundeswehr München (2013)

30. M. Heidt, Gamification: Grundlagen der Implementierung spieltypischer Elemente Wirtschaftskontext [Gamification: Basics of the implementation of game-typical elements Economic context]. Saarbrücken: AV Akademikerverlag (2012) 
31. M. Krstić, N. Pavlović, Behavioral Economics: New Dimension in Understanding the Real Economic Behavior. In Akkucuk, U., Handbook of Research on Sustainable Supply Chain Management for the Global Economy. Hershey: IGI Global, 281-298 (2020)

32. D. K. Richards, M. R. Matthew, A. C. Field, Profiles of motivations for responsible drinking among college students: A self-determination theory perspective. Addictive Behaviors. 111, 106550 (2020)

33. H. Lee, Intrinsic and extrinsic motivations affecting impulse-buying tendency in mobile shopping. Social Behavior and Personality. 46(4), 683-694 (2018)

34. N. Miura, H. C. Tanabe, A. T. Sasaki, Neural evidence fort the intrinsic value of action as motivation for behavior. Neuroscience. 352, 190-203 (2017)

35. R. M. Ryan, E. L. Deci, Self-determination theory and the facilitation of intrinsic motivation, social development, and well-being. American Psychologist. 55(1), 68-78 (2000)

36. D. Dicheva, C. Dichev, G. Agre, G. Angelova, Gamification in Education: A Systematic Mapping Study. Journal of Educational Technology \& Society. 18(3), 75-88 (2015)

37. G. Richter, D. R. Raban, S. Rafaeli, Studying Gamification: The Effect of Rewards and Incentives on Motivation. In: T. Reiners, L. C. Wood, Gamification in Education and Business. Cham: Springer International Publishing, 21-46 (2015)

38. R. M. Ryan, C. S. Rigby, A. Przybylski, The Motivational Pull of Video Games: A Self-Determination Theory Approach. Motivation and Emotion. 30(4), 344-360 (2006)

39. J. Majerova, Analysis of Slovak Consumer's Perception of the Green Marketing Activities. In C. Bektas, Proceedings of the World Conference on Business, Economics and Management (WCBEM). 553-560 (2015)

40. D. Moravcikova, A. Krizanova, J. Kliestikova, Green Marketing as the Source of the Competitive Advantage of the Business. Sustainability. 9(12), 2218 (2017)

41. K. Valaskova, J. Kliestikova, A. Krizanova, Consumer Perception of Private Label Products: An Empirical Research. Journal of Competitiveness. 10(3), 149-163 (2018)

42. S. Deterding, Gamification: Designing For Motivation. Interactions. 19(4), 14-17 (2012)

43. K. Murray, S. Bellman, Playing Games Efficiently: Hedonic Learning and Loyalty. In: G. J. Fitzsimons, V. Moritz, M. N. Duluth. Advances in Consumer Research. MN: Association for Consumer Research, 247-248 (2007)

44. J. C. Siemens, S. Smith, D. Fisher, A. Thyroff, G. Killian, Level Up! The Role of Progress Feedback Type for Encouraging Intrinsic Motivation and Positive Brand Attitudes in Public versus Private Gaming Contexts. Journal of Interactive Marketing. 32, 1-12 (2015)

45. P. Kotler, K. L. Keller, Marketing Management. Hoboken: Pearson Education (2009)

46. D. Dalgleish, Beginning Pivot Tables in Excel 2007. New York: Apress (2007)

47. D. P. Mackinnon, Introduction to Statistical Mediation Analysis. Abingdon: Routlege (2008)

48. CSDT, Intrinsic Motivation Inventory [online]. Available at: https://selfdeterminationtheory.org/intrinsicmotivation-inventory/

49. K. J. Preacher, A. F. Hayes, Asymptotic and resampling strategies for assessing and comparing indirect effects in multiple mediator models. Behavior Research Methods. 40(3), 879-891 (2008)

50. C. S. Rigby, Intrinsic and Extrinsic Player Motivation: Implications for Design and Player Retention. [online]. Celebration, FL: Scott Rigby Immersyve Inc. Available at: https://www.gdcvault.com/play/1015568/Intrinsicand-Extrinsic-Player-Motivation (2012)

51. E. L. Deci, R. M. Ryan, Handbook of self-determination research. Rochester, NY: The University of Rochester Press (2004)

52. F. Rheinber, R. Vollmeyer, S. Engeser, Die Erfassung des Flow-Erlebens. In: J. Stiensmeier-Pelster, F. Rheinberg. Diagnostik von Motivation und Selstkonzept [Diagnostics of motivation and self-concept]. 261-280 (2003)

53. J. Hendl, J. Remr, Metody výzkumu a evaluace [Research and evaluation methods]. Praha: Portál (2017) 